\title{
Development of novel spray freeze-drying method for value-added coffee powder preparation
}

\author{
Jae-Young Her* \\ Department of Food Engineering, Mokpo National University, Muan 58554, Korea \\ 고부가가치 커피 분말 제조를 위한 분무동결건조 기술 개발 \\ 허재영* \\ 국립목포대학교 식품공학과
}

\begin{abstract}
New method for producing a fine powder from commercial soluble coffee using a spray freeze-drying (SFD) technique was investigated. The analysis of aromatic compounds was carried out by headspace solid phase micro-extraction coupled with gas chromatography-mass spectrometry. Scanning electron microscopy and laser particle size analysis were used to characterize the physical structure and size distribution of the SFD-derived particles, respectively. Moreover, the moisture content and color of the SFD powder were evaluated. Eleven key volatile compounds were identified in the commercial soluble coffee pre- and post-SFD. Recoveries of aromatic volatiles ranging from 46.8$100.6 \%$ were observed in the overall flavor profile from the SFD-obtained powder. The particles of the aromatic powder were spherical in nature with highly porous surfaces and a mean diameter of $18.7 \mu \mathrm{m}$. The moisture content of the SFD coffee powder was $4.96 \%$. The total color difference and chroma were $10.74 \pm 0.82$ and $31.94 \pm 0.11$, respectively. This study showed that the SFD technique can be potentially employed for the production of soluble coffee with improved product characteristics.
\end{abstract}

Key words : spray freeze-drying, commercial soluble coffee, volatile retention, SPME/GC-MS

서 론

커피는 전 세계에서 가장 널리 소비되는 음료 중 하나이며 카페인, 폴리페놀 화합물, 니아신, 미네랄(마그네슘, 칼륨) 등 인간의 대사에 영향을 미치는 여러 가지 생리활성성분을 함 유하고 있다. 커피는 폴리페놀 계열인 페놀산을 함유하고 있 어 강력한 항산화, 항염증, 항혈전 효과를 나타낸다(Miranda 등, 2021). 또한 커피 음료는 800 종 이상의 향기성분을 함유하 고 있어 독특한 풍미를 나타낸다(Maarse과 Visscher, 1996). 이러한 독특한 풍미는 커피에 존재하는 케톤류, 알데하이드 류, 퓨란류, 에스테르류, 파이롤류, 피리딘류, 파이라진류, 페
놀류, 카르복실산류, 락톤류, 아민 및 황 화합물 등의 휘발성 성분에 의하여 나타난다(Zapata 등, 2018). 현재 커피는 다양 한 형태로 상업적으로 생산되고 있으며, 특히 인스턴트 커피 의 제조를 위하여 많은 기술이 접목되고 있다(Weschenfelder 등, 2015). 인스턴트 커피는 볶은 커피원두의 추출물을 건조시 켜 분말로 가공한 인스턴트 식품이다(FSSAI, 2011). 이와 같은 인스턴트 커피의 제조를 위하여 일반적으로 분무건조와 동결 건조기술이 사용되고 있다(Ishwarya과 Anandharamakrishnan, 2015).

건조는 일반적으로 저장 및 운송비용을 줄이고 추출물과 같은 액체 제품의 수분 함량을 감소시켜 제품의 미생물학적

*Corresponding author. E-mail : jyher@mokpo.ac.kr, Phone : +82-61-450-2421, Fax : +82-61-454-1521

Received 09 September 2020; Revised 12 November 2020; Accepted 25 November 2020.

Copyright (c) The Korean Society of Food Preservation.

This is an Open Access article distributed under the terms of the Creative Commons Attribution Non-Commercial License (http://creativecommons.org/licenses/by-nc/4.0) which permits unrestricted non-commercial use, distribution, and reproduction in any medium, provided the original work is properly cited. 
안정성을 보장하는데 사용된다(Gharsallaoui 등, 2007; Her 등, 2015a). 건조 방법 및 조건에 따라서 가공 중 향미 보유에 영향을 미치기 때문에 건조 방법의 선정이 매우 중요하다 (Kompany과 Rene, 1995). 식품 산업에서 일반적으로 사용되 는 기술인 분무건조는 운영비용이 낮고 생산 속도가 높다는 장점이 있다(Her 등, 2010). 식품에 특징적인 향을 주는 향기 성분의 대부분은 휘발성이 높기 때문에 분무건조 공정 중에 쉽게 손실된다. 이와 같은 이유로 향미료의 손실을 최소화하 기 위하여 미세 캡슐화 방법 등 다양한 기술들이 보고되었다 (Gharsallaoui 등, 2007). 한편, 동결건조는 본질적으로 낮은 처리량을 갖는 고가의 건조 방법이지만, 공정 중에 식품에 존 재하는 휘발성 성분 및 향기성분의 손실이 적다(Huang 등, 2012; Kompany과 Rene, 1995). 두 가지 건조 기술의 단점을 보완하기 위해, 분무동결건조 기술 개발에 대한 연구가 활발 하게 진행되고 있다. 분무동결건조는 비교적 새로운 건조기 술로 바이오 분말 제제의 제조를 위하여 활용되고 있다(Her 등, 2010).

분무동결건조 기술은 분무건조와 동결건조 공정을 결합하 여 열적 손상이 없는 미세한 형태의 분말을 얻을 수 있다. 분 무동결건조 공정은 액체 시료를 분무함으로써 형성된 액적을 액체질소에 침지시켜 급속 동결 후 동결건조 공정에 의해 건 조한다. 분무동결건조 공정은 높은 열전달 효율로 인해 동결 건조 공정보다 시간이 짧으며, 건조과정 중 분말의 뭉침 현상 을 방지한다(Her 등, 2010). 또한 분무동결건조 공정으로 생 성된 분말은 건조 후 분쇄공정을 필요로 하지 않아 분쇄공정 중 건조시료가 받는 물리적 스트레스를 최소화 할 수 있다 (Her 등, 2015b). 분무동결건조 공정에 의해 생성된 입자는 전형적으로 분무건조 공정에 의해 생성된 입자보다 더 큰 표 면적 및 더 높은 미립자 분율을 갖는다.

분무동결건조 기술은 대부분 제약분야에 이용되었으며, 식품가공분야에 상기 기술을 적용하기 위한 연구는 상당히 제한적이다(Her 등, 2017). 따라서 본 연구에서는 분무동결 건조 전과 후의 휘발성 향기성분의 함량 차이와 최종입자의 물리적 특징을 평가하여 향기성분의 보존성을 높인 고부가가 치 인스턴트 커피 분말을 제조에 분무동결건조 기술의 가능 성을 평가하고자 한다.

\section{재료 및 방법}

\section{재료}

본 연구에서 사용된 커피 용액은 상업적으로 구입 가능한 순수 인스턴트 커피 분말이며, $40 \%(\mathrm{w} / \mathrm{w})$ 의 질량 분율로 증 류수에 용해시켜 제조하였다. $40 \%$ 인스턴트 커피 용액은 분 무공정 직전에 제조하여 사용하였다. n-Alkane 혼합물 표준
시약(C4-C40)은 Supelco사(Bellefonte, PA, USA)로부터 구 입하였고, 내부표준물질로 사용된 quinoxaline은 도쿄 화성 공업(Tokyo, Japan)에서 구매하여 사용하였다. 또한 분석에 사용된 HPLC-grade water는 J.T.Baker(Philipsburg, NJ, USA)에서 구매하여 사용하였다.

\section{분무동결건조 공정}

제조된 $40 \%$ 인스턴트 커피 용액을 $50 \mathrm{~mL} / \mathrm{min}$ 의 유속으 로 $10 \mathrm{~min}$ 동안 노즐 팁 리프트가 $1.0 \mathrm{~mm}$ 인 내부혼합형 이유 체 노즐을 이용하여 분무하였다(Fig. 1). 분무 기압을 $10 \mathrm{kPa}$ 로 설정하고, 생성된 액적을 액체 질소에 침지시켰다. 분무 공정 후, 액체 질소를 함유한 용기를 $-40^{\circ} \mathrm{C}$ 의 냉동기로 옮기 고 $1 \mathrm{~h}$ 동안 방치하여 액체 질소를 증발시켰다. 이어서 샘플 을 동결건조기(Gudero, Ilshin Lab, Dongducheon, Korea)로 옮겨 동결건조를 실시하였다. 동결건조 공정은 $0.133 \mathrm{kPa}$ 의 압력에서 수행되었다. 선반 온도를 $-25^{\circ} \mathrm{C}$ 에서 $4 \mathrm{~h}$ 동안 유지 하고, $4 \mathrm{~h}$ 에 걸쳐 $20^{\circ} \mathrm{C}$ 로 증가시킨 후 $3 \mathrm{~h}$ 동안 유지시켰다. 최종 건조된 분말은 사용할 때까지 $4^{\circ} \mathrm{C}$ 에서 보관하였다.

\section{Solid phase microextraction(SPME)법에 의한 휘발성 향기성분 분석}

휘발성 화합물의 보존에 대한 $\mathrm{SFD}$ 의 영항을 측정하기 위 해 SFD 전과 후의 인스턴트 커피 분말을 SPME/GC-MS로 분석하였다. SFD 전과 후의 커피분말 시료를 각각 $1 \mathrm{~g}$ 씩 20 $\mathrm{mL}$ headspace glass vial에 첨가 후 $9 \mathrm{~mL}$ 의 HPLC-grade water을 첨가하고 silicon/Teflon septum(Supelco, Bellefonte, $\mathrm{PA}, \mathrm{USA}$ )를 이용하여 밀봉하였다. 이후 $20 \mu \mathrm{L}$ 의 n-alkane 혼합물 표준시약 $(10 \mu \mathrm{g} / \mathrm{mL})$ 과 내부표준물질로 사용된 quinoxaline $(1,000 \mu \mathrm{g} / \mathrm{mL})$ 를 $10 \mu \mathrm{L}$ 를 주입하고 혼합하였다. 이 후 평형 시간 및 온도는 각각 $10 \mathrm{~min}$ 및 $70^{\circ} \mathrm{C}$ 이었으며, 동일 온도에서 $15 \mathrm{~min}$ 동안 Divenylbenzene/Carboxen/Polydimethylsiloxane(DVB/CAR/PDMS)를 이용하여 추출한 후 $230^{\circ} \mathrm{C}$ 에서 10 분간 탈착하였다.

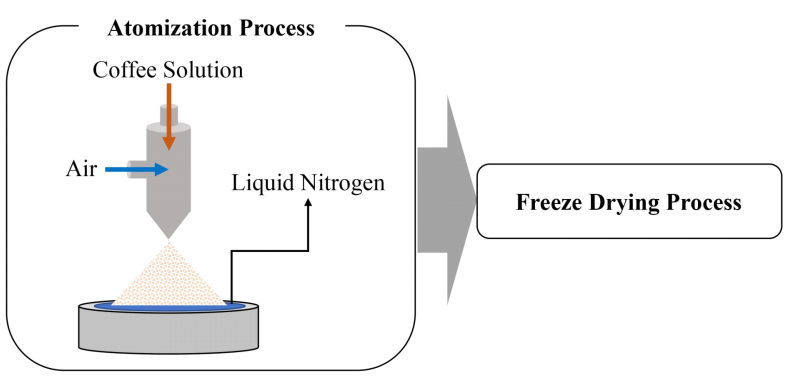

Fig. 1. Schematic diagram of spray freeze-drying method. 


\section{Gas chromatography-mass spectrometry(GC-MS) 분석 및 휘발성 향기성분 동정}

휘발성 화합물 분석은 5975 질량 분석 검출기(Agilent Technologies Inc., Palo Alto, CA, USA) 및 DB-WAX 컬럼 $(60 \mathrm{~m} \times 0.32 \mathrm{~mm}$ i.d. $\times 0.5 \mu \mathrm{m}, \mathrm{J} \& \mathrm{~W}$ Scientific, Folsom, CA, USA)이 장착된 Agilent 6890 가스크로마토그래피 시스 템을 사용하여 수행되었다, 오븐 온도는 초기에 $44^{\circ} \mathrm{C}$ 에서 5 $\min$ 동안 유지된 후, $3^{\circ} \mathrm{C} / \mathrm{min}$ 으로 $170^{\circ} \mathrm{C}$ 로 상승시킨 후 10 $\min$ 동안 유지, 최종적으로 $3^{\circ} \mathrm{C} / \mathrm{min}$ 으로 $240^{\circ} \mathrm{C}$ 로 상승시킨 후 5 분 동안 유지되도록 프로그래밍하였다. 인젝터 온도는 $230^{\circ} \mathrm{C}$ 로 설정되었다. 헬륨 캐리어 가스의 유량은 $1 \mathrm{~mL} / \mathrm{min}$ 이었으며, 인젝션 모드는 splitless였다. 휘발성 화합물은 전자 충격(EI) $70 \mathrm{eV}$ 사중 극자 필터를 사용하여 $\mathrm{MS}$ 에 의해 분석 하였으며, 스캔 범위는 35-350 m/z이었다(Table 1). 머무름 지수와 질량 스펙트럼 데이터를 모두 각 화합물의 식별에 사 용하였다. 휘발성 화합물의 머무름 지수는 동일한 크로마토 그래피 조건에서 C4-C40 n-alkane 혼합물 표준시약을 사용하 여 결정되었으며, Kratz 공식에 따라 계산되었다(Jo 등, 2011). 질량 스펙트럼 데이터는 national institute of standards and technology(NIST)에서 제공하는 질량 스펙트럼 라이브러리 와 비교하였다. 유사성이 750 이상(최대 유사성은 1000)인 화합물만 본 논문에 나타내었다. 휘발성 화합물의 함량은 내 부표준물질에 대한 피크 면적으로 계산되었다.

\section{커피 분말의 물리적 특성 평가}

$\mathrm{SFD}$ 공정 후의 분말 입자의 표면 특성을 평가하기 위해 $\mathrm{SEM}(\mathrm{JSM} 5410 \mathrm{LV}$, JEOL, Tokyo, Japan)을 사용하였다. 건

Table 1. Operation conditions of GC/MS (Agilent GC with MSD detector) analysis

\begin{tabular}{cc}
\hline Instrument & Condition \\
\hline GC & $6890 \mathrm{GC}$, Agilent \\
MSD & 5975 , Agilent \\
\hline Method & \\
\hline Column & DB-WAX $(60 \mathrm{~m} \times 0.32 \mathrm{~mm} \mathrm{i.d.} \times 0.5 \mu \mathrm{m})$ \\
Oven temperature & $44^{\circ} \mathrm{C}(5 \mathrm{~min}), 3^{\circ} \mathrm{C} / \mathrm{min}$ to $170^{\circ} \mathrm{C}(10 \mathrm{~min})$, \\
$3^{\circ} \mathrm{C} / \mathrm{min}$ to $240^{\circ} \mathrm{C}(5 \mathrm{~min})$ \\
Injector temperature & $230^{\circ} \mathrm{C}$ \\
Carrier gas & $\mathrm{He}, \mathrm{mL} / \mathrm{min}$ \\
Split mode & Splitless \\
Measurement mode & Scan \\
Mass range & $35-350 \mathrm{~m} / \mathrm{z}$ \\
\hline
\end{tabular}

조된 분말 샘플을 양면 카본 탭에 부착하고 SEM 지지체 상 에 장착하고, 이를 10 분 동안 얇은 금 층으로 코팅하였다. $\mathrm{SFD}$ 전과 후의 커피 분말의 SEM 이미지는 $100 \times, 500 \times$, $3,000 \times$ 및 $30,000 \times$ 에서 촬영되었다. 레이저 입자 크기 분석 기(LS 13 320, Beckman Coulter, Fullerton, CA, USA)를 사 용하여 입자 크기 및 입자 크기 분포를 측정하였다. 건조된 분말 샘플 $(10 \mathrm{mg})$ 을 $40 \mathrm{~mL}$ 의 에탄올에 분산시킨 다음 분석 하였다.

수분 함량은 건조 시 질량 손실의 중량 측정을 기반으로 분석되었다. 커피 샘플 $1 \mathrm{~g}$ 을 알루미늄 접시에 놓고 열기 오 븐에서 $2 \mathrm{~h}\left(95 \pm 2^{\circ} \mathrm{C}\right)$ 가열하였으며, 3 회 반복 실험을 수행하 여 평균 및 표준편차를 나타내었다. 커피분말의 표면 색상 측 정은 색차계(ZE6000, Nippon Denshoku, Japan)를 사용하여 수행되었다. 커피 샘플을 페트리 접시에 넣고 약간 흔들어 균 일한 표면을 형성한 이후에 변수 $\mathrm{L}^{*}, \mathrm{a}^{*}, \mathrm{~b}^{*}$ 를 측정하였다. 또한 총 색차(total colour difference, $\Delta \mathrm{E}$ ) 및 채도(chroma, $\mathrm{C}^{*}$ )도 계산되었으며, 3 회 반복 실험을 수행하여 평균 및 표 준편차를 나타내었다.

\section{결과 및 고찰}

\section{$\mathrm{SPME}-\mathrm{GC} / \mathrm{MS}$ 를 이용한 분무동결건조 전후 인스턴트 커피의 휘발성 향기성분}

최근 상업용 커피의 향기성분 분석에 많이 사용되고 있는 SPME fiber는 DVB/CAR/PDMS와 CAR/PDMS, PDMS/DVB 이다. 그중에서도 $\mathrm{DVB} / \mathrm{CAR} / \mathrm{PDMS}$ fiber는 커피의 주요 향 기성분 추출속도 연구에 사용되는 등 커피의 향기성분 추출 적합성을 확인하는 연구가 많이 진행되었다(Mestdagh 등 2014). 따라서 본 연구에서도 DVB/CAR/PDMS fiber를 사용 하여 인스턴트 커피의 향기성분을 분석하였다.

인스턴트 커피의 휘발성 향기성분의 총 이온 크로마토그 램은 Fig. 2에 나타내었다. 분무동결건조 공정 전과 후에 유 사한 피크 패턴을 나타내었다. $\mathrm{GC} / \mathrm{MS}$ 분석에 따르면 거의 50 개의 화합물이 분리되고 확인되었다. 확인된 휘발성 물질 중에서 식별된 성분은 케톤류, 알데하이드류, 퓨란류, 에스테 르류, 파이롤류, 피리딘류, 파이라진류, 페놀류, 카르복실산 류, 락톤류를 포함하였다. 커피 향기성분의 $80 \%$ 이상을 차지 하는 주요 성분으로 2-methylpyrazine, furfural, 2,6-dimethylpyrazine, 5-methylfurfural, acetic acid가 알려져 있으며, 특히 furfural, 1H-pyrrole-2-carboxaldehyde, 2,5-dimethylpyrazine, acetic acid, 5-methylfurfural는 로스팅 커피의 최종 향을 구별하는 데 중요한 역할을 하는 것으로 알려져 있다 (Rodrigues 등, 2012). 이를 통하여 11가지의 주요 향기성분 을 선정하였으며, SPME-GC/MS를 사용하여 인스턴트 커피 


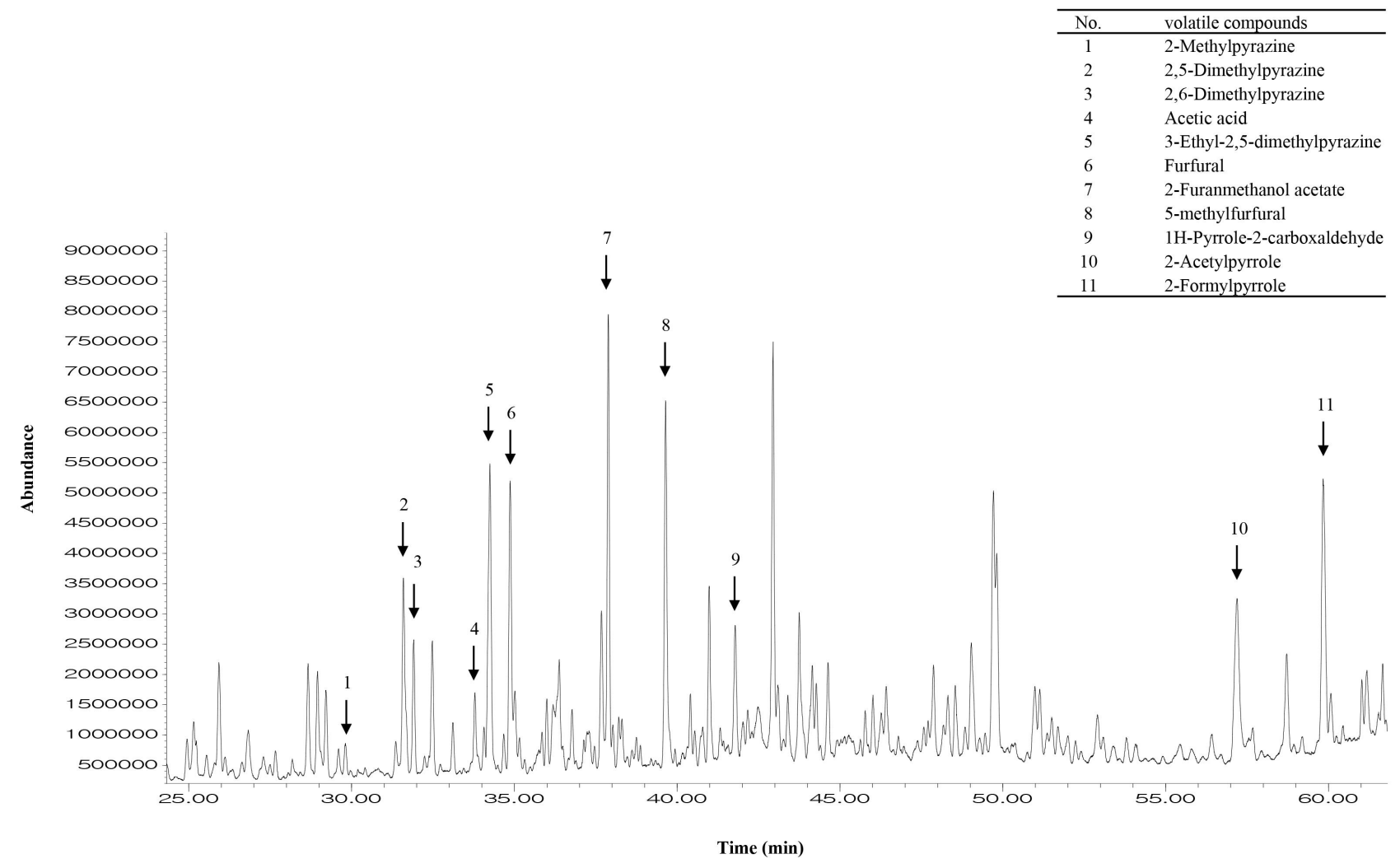

Fig. 2. Total ion chromatogram of volatile compounds isolated from soluble coffee.

의 분무동결건조 후의 주요 휘발성 향기성분의 회수율을 Table 2에 나타내었다. 분무동결건조 전과 후의 건조물에서 11 가지 주요 휘발성 향기성분의 회수 백분율은 $100.6 \%$ 에서 $46.8 \%$ 로 나타났다.

분무동결건조 전과 후의 휘발성 성분의 회수율을 비교분 석한 연구는 매우 제한적이다. 표고버섯 추출물의 분무동결 건조 전과 후의 대표적인 향기성분 비교연구에 따르면 회수 율은 $72.1 \%$ 에서 $30.9 \%$ 로 나타났다(Her 등, 2015b). 특히 대 부분의 식용 버섯에서 버섯 고유의 풍미를 부여하는 대표적 인 휘발물질 중 하나인 1-octen-3-ol의 회수율은 분무동결건 조 공정 후 $82.9 \%$ 로 매우 높은 회수율을 나타내었다. Chin 등(2008)은 동결건조 처리 전과 후의 두리안 펄프에 존재하 는 대표적인 휘발성 성분의 양을 보고했으며, 상기 연구에 따 르면 동결건조 처리 후 두리안 펄프 샘플로부터 주요 방향족 휘발성 물질이 $97.5 \%$ 까지 감소했다(Chin 등, 2008). 이전 연 구에 따르면, 동결건조공정 중 시료에서 휘발성 성분의 감소 는 대부분 얼음의 승화단계와 건조물 시료의 분쇄단계(분쇄를 통한 분말 생성단계)에서 발생한다(Chin 등, 2008; Krokida과 Philippopoulos, 2006). 그러나 분무동결건조는 높은 열 전달 계수로 인해 동결건조보다 공정 시간이 짧고 시료는 얼음 승
화 단계에 노출되는 시간을 감소시킬 수 있다. 또한, 분무동 결건조 공정으로 생성된 분말은 건조 후 분쇄 공정을 필요로 하지 않고 비교적 균일한 평균 입자 크기를 제공한다(Her 등, 2010). 본 연구에서 획득한 분무동결건조 시료의 높은 휘발 성 향기성분의 회수율은 동결건조 공정 시간 단축과 분쇄공 정 미처리에 기인한다고 판단된다.

\section{분무동결건조 전후 인스턴트 커피의 물리적 특성}

분무동결건조 공정 전과 후 인스턴트 커피 분말의 주사전 자현미경(SEM) 이미지는 Fig. 3에 나타내었다. 분무동결건 조 처리 전 인스턴트 커피의 입자는 다공성 구조를 가지고 있지만, 입자의 크기 및 모양이 매우 불규칙함을 확인할 수 있었다. 그러나 분무동결건조 처리를 거친 인스턴트 커피는 다공성의 매우 작은 구형의 입자를 형성함을 확인할 수 있었 다. 일반적으로 작은 입자 크기, 낮은 수분 함량 및 다공성의 조합으로 인하여 휘발성 성분의 손실 및 수분 흡수가 촉진된 다(Her 등, 2015b). 그러나 높은 다공성 표면을 갖는 입자를 함유하는 분말 시료는 우수한 재수화 특성 때문에 식품 산업 에 바람직하다(Liapis과 Bruttini, 2009; Maa 등, 1999). 또한, 구형 입자는 산업현장에서 공정의 흐름을 향상시킬 수 있다 
Table 2. Major volatile compounds of soluble coffee extracts pre- and post-SFD

\begin{tabular}{|c|c|c|c|c|c|c|}
\hline \multirow{2}{*}{ Peak no. } & \multirow{2}{*}{$\mathrm{RI}^{1)}$} & \multirow{2}{*}{ Compound } & \multicolumn{2}{|c|}{ Relative peak area ${ }^{2)}$} & \multirow{2}{*}{$\begin{array}{l}\text { Percent of } \\
\text { recovery }(\%)\end{array}$} & \multirow{2}{*}{$\begin{array}{c}\text { Odor } \\
\text { description }\end{array}$} \\
\hline & & & Pre-SFD & Post-SFD & & \\
\hline 1 & 1378 & 2-Methylpyrazine & 0.171 & 0.080 & 46.8 & Roasted \\
\hline 2 & 1437 & 2,5-Dimethylpyrazine & 0.144 & 0.132 & 91.7 & Roasted \\
\hline 3 & 1443 & 2,6-Dimethylpyrazine & 0.136 & 0.071 & 52.2 & Roasted \\
\hline 4 & 1553 & Acetic acid & 0.425 & 0.344 & 80.9 & Burnt \\
\hline 5 & 1562 & $\begin{array}{c}\text { 3-Ethyl-2,5- } \\
\text { dimethylpyrazine }\end{array}$ & 0.14 & 0.095 & 67.9 & Roasted \\
\hline 6 & 1570 & Furfural & 0.737 & 0.346 & 46.9 & Almond \\
\hline 7 & 1642 & 2-Furanmethanol acetate & 0.308 & 0.310 & 100.6 & Roasted \\
\hline 8 & 1683 & 5-Methylfurfural & 0.543 & 0.282 & 51.9 & \\
\hline 9 & 1736 & $\begin{array}{l}\text { 1H-Pyrrole-2- } \\
\text { carboxaldehyde }\end{array}$ & 0.106 & 0.079 & 74.5 & Burnt \\
\hline 10 & 2077 & 2-Acetylpyrrole & 0.433 & 0.318 & 73.4 & \\
\hline 11 & 2106 & 2-Formylpyrrole & 0.645 & 0.634 & 98.3 & \\
\hline
\end{tabular}

${ }^{1)}$ Retention 12 index calculated on DB-WAX fused silica capillary column.

${ }^{2)}$ Relative peak areas to that of internal standard.

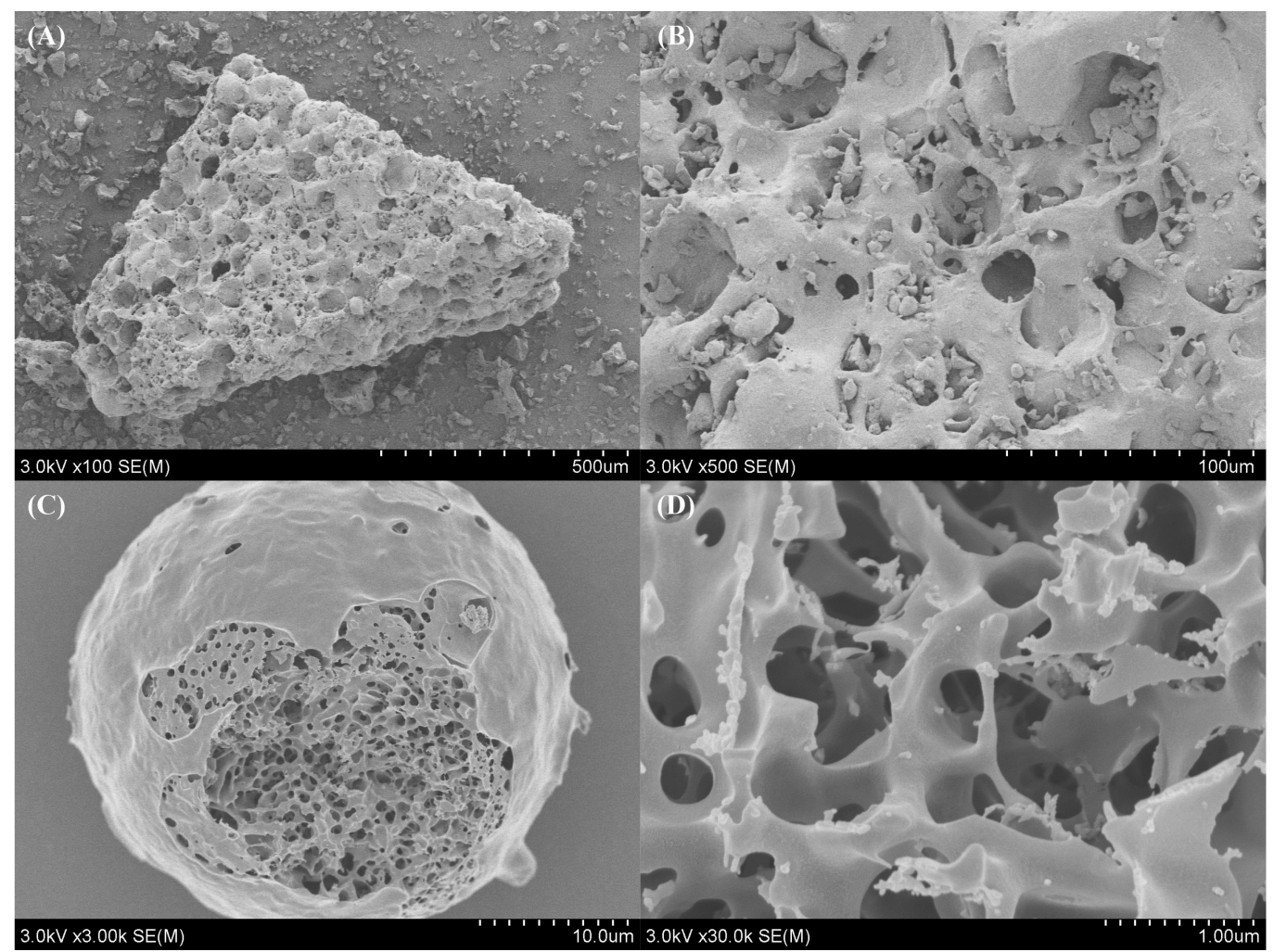

Fig. 3. Scanning electron microscopy (SEM) image of coffee powder.

A, soluble coffee powder before SFD $(100 \times)$; B, soluble coffee powder before SFD $(500 \times)$; C, SFD coffee powder $(3,000 \times)$; D, SFD coffee powder $(30,000 \times)$. 
(Kabra 등, 2013).

입자 크기 분포는 여러 모델을 기반으로 계산할 수 있으며, 대부분 입자의 수 또는 부피 분포로 나타낸다. Fig. 4에 나타 낸 바와 같이 분말의 평균 입자 직경(부피 분포)은 $18.7 \mu \mathrm{m}$ 이며, 평균 수 분포의 결과는 $1.99 \mu \mathrm{m}$ 였다. SFD 분말의 입자 크기 분포는 전통방식의 동결건조와 달리 분무조건(nozzle tip lift, 공기압력, 커피수용액의 흐름 속도)과 어닐링 처리 조 건의 변화를 통하여 쉽게 조절이 가능하다(Her 등, 2010). 따 라서 산업현장의 요구 조건에 쉽게 부합하는 크기의 입자 생 산이 가능하다. 기존연구에 따르면 분무동결건조된 가나마이 신 입자의 크기는 분무조건과 어닐링 처리 조건에 따라 평균 입자 직경이 $13.5 \mu \mathrm{m}$ 에서 $21.8 \mu \mathrm{m}$ 를 나타내었다(Her 등, 2010).

수분함량은 인스턴트 커피분말 취급에 매우 중요한 역할 을 한다. 탈수된 분말 중의 수분으로 인하여 입자간 응집력이 증가하며, 이로 인하여 케이킹 현상 발생 및 가공공정 중의 흐름 장애를 유발하게 된다. 분무동결건조 공정 전과 후 인스 턴트 커피 분말의 수분함량은 각각 $6.99 \%$ 와 $4.96 \%$ 로 분무동 결건조된 커피 분말의 수분함량이 시중에 판매되고 있는 인 스턴트 커피보다 낮은 수준임을 확인하였다(Table 3).

인스턴트 커피의 색상은 주요 품질 지표 및 소비자의 선호 기준 중 하나이다. 일부 소비자는 진한 색의 커피를 선호하는 반면 다른 소비자는 더 밝은 색의 커피를 선호한다. 분무동결 건조 전의 상업용 인스턴트 커피의 $\mathrm{L}^{*}, \mathrm{a}^{*}, \mathrm{~b}$ *와 $\mathrm{C}^{*}$ 값은 각 각 $32.87 \pm 0.53,14.25 \pm 0.21,25.29 \pm 0.22,29.03 \pm 0.10$ 을 나타

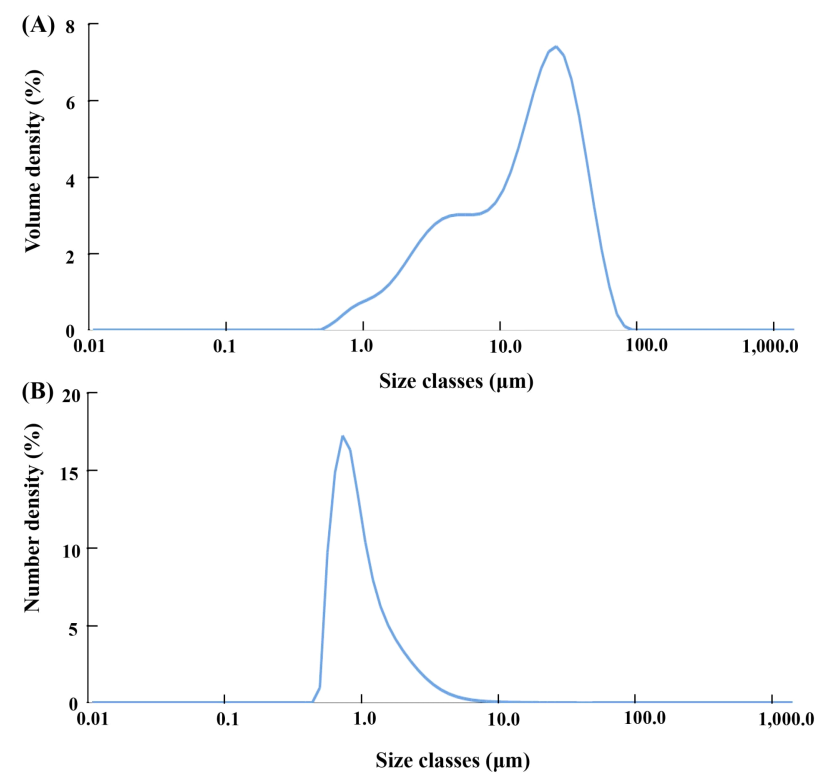

Fig. 4. Particle size distribution of spray freeze-dried coffee powder. A, differential volume; $B$, differential number.
Table 3. Comparison of physical characteristics between pre- and post-spray freeze-dried soluble coffee samples

\begin{tabular}{cccc}
\hline & & Pre-SFD & Post-SFD \\
\hline Moisture content $(\%)$ & $6.99 \pm 0.26^{1)}$ & $4.96 \pm 0.26$ \\
\hline & $\mathrm{L}^{*}$ & $32.87 \pm 0.53$ & $42.98 \pm 0.25$ \\
& $\mathrm{a}^{*}$ & $14.25 \pm 0.21$ & $13.66 \pm 0.06$ \\
Color & $\mathrm{b}^{*}$ & $25.29 \pm 0.22$ & $28.87 \pm 0.12$ \\
& $\mathrm{C}^{* 2}$ & $29.03 \pm 0.10$ & $31.94 \pm 0.11$ \\
& $\Delta \mathrm{E}^{3)}$ & - & $10.74 \pm 0.82$ \\
\hline
\end{tabular}

${ }^{1)}$ All values are expressed as the mean $\pm \mathrm{SD}$ of triplicate determinations. ${ }^{2)} \mathrm{C}^{*}=\left(\mathrm{a}^{*^{2}}+\mathrm{b}^{*^{2}}\right)^{1 / 2}$

${ }^{3)} \Delta \mathrm{E}=\left\{\left(\mathrm{L} *_{2}-\mathrm{L}_{1}\right)^{2}+\left(\mathrm{a}_{2}-\mathrm{a} *_{1}\right)^{2}+\left(\mathrm{b}_{2}-\mathrm{b}_{1}\right)^{2}\right\}^{1 / 2}$

내었다(Table 3). 동일한 커피시료는 아니지만 기존 연구에서 나타난 상업용 인스턴트 커피의 $\mathrm{L}^{*}, \mathrm{a}^{*}, \mathrm{~b}$ *와 $\mathrm{C}^{*}$ 값은 각각 $35.44,13.75,25.47,28.94$ 으로 본 연구에서의 실험결과와 매 우 유사한 수치를 나타내었다. 분무동결건조된 커피 분말의 색도 $\mathrm{L}^{*}, \mathrm{a}^{*}, \mathrm{~b}$ *와 $\mathrm{C}^{*}$ 값은 $42.98 \pm 0.25,13.66 \pm 0.06,28.87 \pm$ $0.12,31.94 \pm 0.11$ 을 나타내었다(Table 2). 분무동결건조 전과 후의 $\mathrm{C}^{*}$ 값은 매우 유사한 수치를 보인 반면, 분무동결건조된 분말의 높은 $\mathrm{L} *$ 값으로 인하여 $\Delta \mathrm{E}$ 는 $10.74 \pm 0.82$ 라는 비교적 높은 수치가 확인되었다. Sharma 등(2013)에 따르면 입자 크 기가 감소함에 따라 $\mathrm{L} *$ 값이 증가하면서 분말의 밝기에 대한 입자 크기의 상당한 영향을 받는다는 결과와 일치하였다. 분 무동결건조된 입자의 평균 직경은 $18.7 \mu \mathrm{m}$ 로 상업용 인스턴 트의 커피에 비하며 매우 작은 입자 크기를 나타내기 때문에 상대적으로 높은 $\mathrm{L}^{*}$ 값이 측정되었다고 생각된다.

분무동결건조 전과 후의 인스턴트 커피 건조물에 존재하 는 11 가지 주요 휘발성 향기성분의 회수 백분율은 $100.6 \%$ 에 서 $46.8 \%$ 로 매우 높은 향기성분 보존률을 나타내었으며, 동 결건조된 인스턴트 커피분말에 비하여 작고 균일한 입자를 갖는 분말을 획득할 수 있었다. 또한, 분무동결건조 전과 후 의 매우 유사한 $\mathrm{C}^{*}$ 수치를 나타내었다. 본 연구를 통하여 휘 발성 향기분의 보존성을 높인 인스턴트 커피 생산을 위한 분 무동결건조 기술의 적용 가능성을 확인하였다.

\section{요 약}

본 연구에서는 인스턴트 커피에 존재하는 휘발성 향기성 분의 보존에 대한 분무동결건조의 효과를 GC-MS과 결합된 헤드 스페이스 $\mathrm{SPME}$ 를 사용하여 정성 및 정량적으로 평가 하였다. 커피의 주요 휘발성 향기성분으로 선정된 11종의 물 질에 대한 SFD 보존 효과는 $46.8 \%$ 에서 $100.6 \%$ 범위였다. 분무동결건조된 커피분말 입자의 평균 직경은 $18.7 \mu \mathrm{m}$ 였으 
며 다공성 표면을 나타내었다. 또한, 분무동결건조 전과 후의 수분함량은 각각 $6.99 \%$ 과 $4.96 \%$ 였다. 분무동결건조 전과 후 의 $\mathrm{C}^{*}$ 값은 $31.94 \pm 0.11$ 로 매우 유사한 수치를 보인 반면, 분무 동결건조된 분말의 높은 $\mathrm{L}^{*}$ 값으로 인하여 $\Delta \mathrm{E}$ 는 $10.74 \pm 0.82$ 라는 비교적 높은 수치가 확인되었다. 이는 분무동결건조된 커피 분말의 입자 매우 작은 크기를 나타내기 때문이다. 본 연구를 통하여 휘발성 향기분의 보존성을 높인 인스턴트 커 피 생산을 위한 분무동결건조 기술의 적용 가능성을 확인하 였다.

\section{감사의 글}

본 논문은 2018학년도 목포대학교 교내연구과제 지원에 의하여 연구되었습니다.

\section{Conflict of interests}

The authors declare no potential conflict of interest.

\section{ORCID}

Jae-Young Her https://orcid.org/0000-0003-1304-0717

\section{References}

Chin ST, Nazimah SAH, Quek SY, Man YBC, Rahman RA, Hashim DM. Changes of volatiles' attribute in durian pulp during freeze- and spray-drying process. LWTFood Sci Technol, 41, 1899-1905 (2008)

FSSAI. Food Safety and Standards (Food Products Standards and Food Additives) Regulations. https://www.fssai.gov. in/upload/uploadfiles/files/Food_Additives_Regulations. pdf (accessed August 2020)

Gharsallaoui A, Roudaut G, Chambin O, Voilley A, Saurel R. Applications of spray-drying in microencapsulation of food ingredients: An overview. Food Res Int, 40, 11071121 (2007)

Her JY, Kim MS, Kim MK, Lee KG. Development of a spray freeze-drying method for preparation of volatile shiitake mushroom (Lentinus edodes) powder. Int J Food Sci Technol, 50, 2222-2228 (2015)

Her JY, Kim MS, Lee KG. Preparation of probiotic powder by the spray freeze-drying method. J Food Eng, 150, 70-74 (2015)
Her JY, Lee KG. Effect of the solvent composition and annealing process on the preparation of spray freezedried acetaminophen powder. Dry Technol, 35, 625- 630 (2017)

Her JY, Song CS, Lee SJ, Lee KG. Preparation of kanamycin powder by an optimized spray freeze-drying method. Powder Technol, 199, 159-164 (2010)

Huang L, Zhang M, Wang L, Mujumdar AS, Sun D. Influence of combination drying methods on composition, texture, aroma and microstructure of apple slices. LWTFood Sci Technol, 47, 183-188 (2012)

Ishwarya SP, Anandharamakrishnan C. Spray-Freeze-Drying approach for soluble coffee processing and its effect on quality characteristics. J Food Eng. 149, 171-180 (2015)

Jo YJ, Cho IH, Song CK, Shin HW, Kim YS. Comparison of fermented soybean paste (Doenjang) prepared by different methods based on profiling of volatile compounds. J Food Sci, 76, 368-379 (2011)

Kabra D, Deshpande A, Deshpande S. Spherical crystallization as particle engineering technique to improve processability of poor flowing furosemide. Int $\mathrm{J}$ Pharm Sci Nanotech, 6, 1990-1993 (2013)

Kompany E, Rene F. A note on the freeze-drying conditions for improved aroma retention in cultivated mushrooms (Agaricus bisporus). LWT-Food Sci Technol, 28, 238240 (1995)

Krokida MK, Philippopoulos C. Volatility of apples during air and freeze drying. J Food Eng, 73, 135-141 (2006)

Liapis AI, Bruttini R. A mathematical model for the spray freeze drying process: The drying of frozen particles in trays and in vials on trays. Int J Heat Mass Transfer, 52, 100-111 (2009)

Maa YF, Nguyen PA, Sweeney T, Shire SJ, Hsu CC. Protein inhalation powders: Spray drying vs spray freeze drying. Pharm Res, 16, 249-254 (1999)

Maarse H, Visscher CA. Volatile Compounds in Foods: Quantitative and Qualitative Data. 7th ed, TNO Food Analysis Institute, Zeist, Netherlands, p 45-46 (1996)

Mestdagh F, Davidek T, Chaumonteuil M, Folmer B, Blank I. The kinetics of coffee aroma extraction. Food Res Int, 63, 271-274 (2014)

Miranda AM, Goulart AC, Bensenor IM, Lotufo PA, Marchioni DM. Coffee consumption and risk of hypertension: A prospective analysis in the cohort study. Clini 
Nutr, 40, 542-549 (2021)

Rodrigues CII, Hanson CM, Nogueira JMF. Coffees and industrial blends aroma profile discrimination according to the chromatic value. Coffee Sci, 7, 167-176 (2012) Sharma M, Kadam DM, Chadha S, Wilson RA, Gupta RK. Influence of particle size on physical and sensory attributes of mango pulp powder. Int Agrophys, 27, 323-328 (2013)
Weschenfelder TA, Lantin P, Viegas MC, Castilhos F, Scheer AP. Concentration of aroma compounds from an industrial solution of soluble coffee by pervaporation process. J Food Eng, 159, 57-65 (2015)

Zapata J, Londono V, Naranjo M, Osorio J, Lopez C, Quintero M. Characterization of aroma compounds present in an industrial recovery concentrate of coffee flavour. CYTA J Food, 16, 367-372 (2018) 